\title{
Summer Food Habits of Domestic Sheep in Southeastern Montana
}

\author{
LYNN E. ALEXANDER, DANIEL W. URESK, AND RICHARD M. HANSEN
}

\begin{abstract}
The summer food habits of sheep were investigated in a sagebrush-grass rangeland in southeastern Montana. Grasses and sedges made up $96 \%$ of the diets. Prairie sandreed (40\%), needleleaf sedge $(28 \%)$, and western whentgrass $(20 \%)$ were the most important foods. Forbs and shrubs made up less than 1 and $3 \%$ of sheep diets, respectively.
\end{abstract}

Sheep ranching is a major industry on southeastern Montana sagebrush-grass rangeland. Until now nothing has been published on the food habits of sheep in southeastern Montana. Some information on sheep food habits has been reported from Colorado, Utah, and Idaho rangelands (Harniss and Wright 1982, MacCracken and Hansen 1981, Cook et al. 1967, Cook et al. 1965, Cook et al. 1961, Cook et al. 1948, and Doran 1943). Sheep diets have been reported for high desert ranges of Utah and Wyoming (Cook et al. 1962, Severson and May 1967, Olsen and Hansen 1977) and annual grasslands of California (Heady and Torell 1959). Kautz and Van Dyne (1978) reported sheep diets on the shortgrass prairie of northeastern Colorado, which had grasses similar to those in southeastern Montana. The objective of this investigation was to determine the summer food habits of sheep grazing on big sagebrush (Artemisia tridentata)-buffalograss (Buchloe dactyloides) rangeland in southeastern Montana.

\section{Study Area and Methods}

The study area was located in southeastern Montana approximately $5 \mathrm{~km}$ directly west of the town of Alzada. Most of this rangeland was under private ownership with some Bureau of Land Management (BLM) allotments. Historically, this area has been grazed by livestock since the mid-1800's. The study area was characterized by moderately rolling hills dominated by a sagebrushbuffalograss plant community bordered on the south by Black Hills ponderosa pine (Pinus ponderosa) and bur oak (Quercus macrocarpa) forest. Elevations ranged from approximately $1000 \mathrm{~m}$ to $1100 \mathrm{~m}$, and average annual precipitation was $37 \mathrm{~cm}$.

Twenty fresh fecal pellet groups were randomly collected from sheep over a 2-day period during June, July, and August 1979. After oven drying 48 hours at $65^{\circ} \mathrm{C}$, the pellets were ground with a Wiley mill through a $1-\mathrm{mm}$ mesh screen. Five microscope slides were made of each sample. Twenty fields were examined per slide, and the fragments of plant species in the fecal material were identified and quantified as described by Sparks and Malecheck (1968).

Vegetation data were collected simultaneously with collection of fecal pellets on 4 locations $(50 \mathrm{~m} \times 60 \mathrm{~m})$ within the study area. Frequency of occurrence was obtained by the Daubenmire (1959) procedure. Three parallel $50-\mathrm{m}$ transects were placed $30 \mathrm{~m}$ apart at each site. Frequency was determined in 50 quadrats $(20 \mathrm{~cm} \times 50$

Alexander was research associate and Hansen is professor with the Range Science Department, Colorado State University, Fort Collins. Uresk is research biologist with the Rocky Mountain Forest and Range Experiment Station, Rapid City, S. Dak., in cooperation with South Dakota School of Mines and Technology.

The a uthors wish to thank the Fosters of Wyotana Ranch for their cooperation and assistance in this study.

Manuscript received April 12, 1982. cm) systematically spaced at $1-\mathrm{m}$ intervals along each line transect. Data were summarized by transect and averaged over the 4 locations.

Standing crop biomass of plants was determined in 10 quadrats $(20 \mathrm{~cm} \times 50 \mathrm{~cm}$ ) systematically spaced at $5-\mathrm{m}$ intervals along 2 transects. All plant material was harvested at ground level at the end of July, air dried for 2 weeks then oven dried at $60^{\circ} \mathrm{C}$ for 24 hours, and weighed. Estimates of standing crop biomass of big sagebrush were determined following the procedures of Uresk et al. (1977).

Similarities between botanical composition in sheep diets and composition on the rangelands were compared using Kulcynski's similarity index (Oosting 1956) and Spearman's rank order correlation. A Chi square contingency table was used to test for monthly differences in sheep diets.

\section{Results and Discussion}

Western wheatgrass (Agropyron smithii) needleleaf sedge (Carex eleocharis), (Table 1) and prairie junegrass (Koeleria cristata) occurred most frequently on the range throughout the summer. Prairie sandreed (Calamovilfa longifolia), blue grama (Bouteloua gracilis), and tumblegrass (Schedonnardus paniculatus) were common only during the months of July and August. However, frequency of green needlegrass (Stipa viridula) was high in June but not in July and August. Changes in plant frequency were a result of growth characteristics of the species, sheep use, and below-normal precipitation. Forb frequency of occurrence was low except for common yarrow (Achillea millefolium) and common dandelion (Taraxacum officinale). Big sagebrush and plains prickly pear (Opuntia polyacantha) were the dominant shrubs, expressing the highest frequencies. Lichen (Parmelia chlorochroa) was frequent throughout the study area.

Western wheatgrass, prairie sandreed, needleleaf sedge, and green needlegrass provided most of the aboveground biomass of forage (Table 1). The aboveground dry weight of grasses and sedges was approximately $363 \mathrm{~kg} / \mathrm{ha}$. Forbs made up about $4 \%$ of the total aboveground biomass. Shrubs provided $341 \mathrm{~kg} / \mathrm{ha}$ of standing crop biomass. Big sagebrush made up $252 \mathrm{~kg} / \mathrm{ha}$, of which only $37 \mathrm{~kg} / \mathrm{ha}$ were leaves. Total estimated aboveground biomass on the study area was $733 \mathrm{~kg} / \mathrm{ha}$.

Grasses and sedges were the major foods of sheep: $96 \%$ in June, 98\% in July, and $94 \%$ in August (Table 1). Botanical composition of sheep diets were different among months $(P<0.01)$. Forty-seven plant species were identified in sheep pellets. These included 22 monocots, 14 forbs, 9 shrubs, and 2 trees. Western wheatgrass, common witchgrass (Panicum capillare), prairie sandreed, and needleleaf sedge made up $90 \%$ of the sheep diets. It is possible that excessive grazing by sheep could reduce cover and frequency of perennial grasses and sedges. Forbs comprised less than $1 \%$ of the diet. Common yarrow, prickly lettuce (Lactuca serriola), and scarlet globemallow (Sphaeralcea coccinea) were the most common forbs eaten by sheep, each making up less than $1 \%$ of the total dict. Big sagebrush comprised nearly $2 \%$ of the diet in June, $0.2 \%$ in July, and $0.7 \%$ in August. Ponderosa pine and bur oak were ingested by sheep in relatively low quantities, $0.3 \%$ and $2 \%$, respectively. 
Table 1. Means and standard errors $(\bar{x} \pm$ se) of dry weight composition of selected plants in the diets of domestic sheep, percent range frequencies, and aboveground dry weight biomasses during summer 1979 near Alzada, Montana.

\begin{tabular}{|c|c|c|c|c|c|c|c|}
\hline \multirow[b]{2}{*}{ Names of Plants } & \multicolumn{3}{|c|}{ Percent in diets } & \multicolumn{3}{|c|}{ Percent frequency } & \multirow{2}{*}{$\begin{array}{l}\begin{array}{c}\text { Aboveground } \\
\text { Biomass } \\
\text { kg/ha }\end{array} \\
\text { Late July } \\
\bar{x} \pm \text { se }\end{array}$} \\
\hline & $\begin{array}{c}\text { June } \\
\bar{x} \pm \text { se }\end{array}$ & $\begin{array}{c}\text { July } \\
\bar{x} \pm \text { se }\end{array}$ & $\begin{array}{l}\text { August } \\
\bar{x} \pm \text { se }\end{array}$ & $\begin{array}{c}\text { June } \\
\bar{x} \pm \text { se }\end{array}$ & $\begin{array}{c}\text { July } \\
\bar{x} \pm \text { se }\end{array}$ & $\begin{array}{l}\text { August } \\
\bar{x} \pm \text { se }\end{array}$ & \\
\hline $\begin{array}{l}\text { Prairie sandreed } \\
\text { Needleleaf sedge } \\
\text { Western wheatgrass } \\
\text { Common witchgrass } \\
\text { Green needlegrass } \\
\text { Common yarrow } \\
\text { Common dandelion } \\
\text { Big sagebrush } \\
\text { Plains prickly pear }\end{array}$ & $\begin{array}{l}22 \pm 2 \\
48 \pm 3 \\
13 \pm 2 \\
4 \pm<1 \\
1 \pm<1 \\
1 \pm<1 \\
2 \pm<1\end{array}$ & $\begin{array}{l}47 \pm 3 \\
15 \pm 2 \\
31 \pm 3 \\
2 \pm<1 \\
1 \pm<1 \\
1 \pm<1 \\
1 \pm<1\end{array}$ & $\begin{array}{l}51 \pm 4 \\
21 \pm 3 \\
17 \pm 3 \\
2 \pm<1 \\
1 \pm<1 \\
1 \pm<1 \\
1 \pm<1\end{array}$ & $\begin{array}{c}59 \pm 13 \\
55 \pm 11 \\
4 \pm 4 \\
48 \pm 9 \\
26 \pm 8 \\
14 \pm 7 \\
24 \pm 9 \\
20 \pm 7\end{array}$ & $\begin{array}{l}47 \pm 9 \\
70 \pm 12 \\
57 \pm 11 \\
6 \pm 4 \\
2 \pm 1 \\
21 \pm 7 \\
12 \pm 7 \\
24 \pm 8 \\
19 \pm 7\end{array}$ & $\begin{array}{l}47 \pm 9 \\
66 \pm 12 \\
59 \pm 11 \\
6 \pm 4 \\
2 \pm 1 \\
24 \pm 8 \\
16 \pm 9 \\
23 \pm 9 \\
20 \pm 8\end{array}$ & $\begin{array}{c}96 \pm 44 \\
61 \pm 15 \\
136 \pm 22 \\
3 \pm 3 \\
36 \pm 15 \\
15 \pm 5 \\
6 \pm 2 \\
37 \pm 51 \\
88 \pm 50\end{array}$ \\
\hline
\end{tabular}

'Big sagebrush dry weight aboveground was $215 \mathrm{~kg} /$ ha woody material and $37 \mathrm{~kg} /$ ha leaves.

Similarity indices between sheep diets and available plants were $36 \%, 37 \%$, and $40 \%$ for June, July, and August, respectively. Significant $(P<0.01)$ negative Spearman's ranked order correlation coefficients $\left(r_{\mathbf{s}}\right)$ for sheep diet preference indices and forage plants were $-0.57,-0.49$, and -0.52 for June, July, and August, respectively. The negative correlation coefficients indicated that sheep were seeking plants that were not abundant on the range.

Plants available on the range and not found in the sheep diets were Louisiana sagebrush (Artemisia ludoviciana), Missouri goldenrod (Solidago missouriensis), common dandelion, Patagonia Indianwheat (Plantago spinulosa), pussytoes (Antennaria parvifolia), rose (Rosa sp.), and plains prickly pear. Of these species, common dandelion has fragile cell walls and very thin cuticle coverings, but we do not believe dandelion could have been overlooked if it was present in even a fraction of a percentage in sheep diets. Plains prickly pear is occasionally underestimated but seldom overlooked by microscopic techniques. The similarity indices and Sperman's correlations indicate that sheep ate few forbs and shrubs because they preferred grasses and sedges.

This study showed that sheep were primarily monocot consumers in southeastern Montana during 1979, with 4 species comprising the majority of their diets. However, most authors concluded that sheep prefer forbs and browse to grasses and sedges (Cook et al. 1948, Doran 1943, Cook et al. 1965, Cook et al. 1961). Our study indicates that sheep do not always prefer forbs and browse as indicated in past studies. MacCracken and Hansen (1981) previously arrived at the same conclusion.

\section{Literature Cited}

Cook, C.J., C.W. Cook, and L.E. Harris. 1948. Utilization of northern Utah summer range plants by sheep. J. Forest.46:416-425.
Cook, C.W., J.E. Mattox, and L.E. Harris. 1961. Comparative daily consumption and digestibility of summer range forage by wet and dry ewes. J. Animal Sci. 20:866-870.

Cook, C.W., K. Taylor, and L.E. Harris. 1962. The effect of range condition and intensity of grazing upon daily intake and nutritive value of the diet on desert ranges. J. Range Manage. 15:1-6.

Cook, C.W., M. Kothmann, and L.E. Harris. 1965. Effect of range condition and utilization on nutritive intake of sheep on summer ranges. $J$. Range Manage. 18:69-73.

Cook, C.W., L.E. Harris, and M.C. Young. 1967. Botanical and nutritive content of diets of cattle and sheep under single and common use on mountain ranges. J. Animal Sci. 26:1169-1174.

Daubenmire, R. 1959. A canopy-coverage method of vegetation analysis. Northwest Sci. 33:43-64.

Doran, C.W. 1943. Activities and grazing habits of sheep on summer ranges. J. Forest. 41:253-258.

Harniss, R.O., and H.A. Wright. 1982. Summer grazing of sagebrush-grass range by sheep. J. Range Manage. 35:13-17.

Heady, H.F, and D.T. Torell. 1959. Forage preference exhibited by sheep with esophageal fistulas. J. Range Manage. 12:28-34.

Kautz, J.E., and G.M. Van Dyne. 1978. Comparative analyses of diets of bison, cattle, sheep, and pronghorn antelope on shortgrass prairie in northeastern Colorado, U.S.A. Proc. 1st Int. Rangeland Congr.

MacCracken, J.G., and R.M. Hansen. 1981. Diets of domestic sheep and other large herbivores in southcentral Colorado. J. Range Manage. 34:242-243.

Olsen, F.W., and R.M. Hansen. 1977. Food relations of wild free-roaming horses to livestock and big game, Red Desert, Wyoming. J. Range Manage. 30:17-20.

Oosting, H.J. 1956. The study of plant communities. W.H. Freeman and Co., San Francisco, Calif.

Severson, K.E., and M. May. 1967. Food preferences of antelope and domestic sheep in Wyoming's Red Desert. J. Range Manage. 20:21-25.

Sparks, D.R., and J.C. Malecheck. 1968. Estimating percentage dry weight in diets using a microscope technique. J. Range Manage. 21:264-265.

Uresk, D.W., R.O. Gilbert, and W.H. Rickard. 1977. Sampling big sagebrush for phytomass. J. Range Manage. 30:311-314. 